\title{
The Effectiveness of Using Android Application to Increase Hijaiyyah Letters Pronunciation Skill
}

\author{
Nandyasari H Putri ${ }^{1}$, Aini Khairunnisa ${ }^{2}$ \\ \{1nandyasariehp@gmail.com, ${ }^{2}$ ainirazak9@gmail.com\} \\ 1,2 Universitas Islam Negeri Maulana Malik Ibrahim, Jalan Gajayana No. 50, Malang, Indonesia
}

\begin{abstract}
Learning Arabic is supported by the correct pronunciation of hijaiyyah letters to minimize the mistaken meaning of Arabic words. At the State University of Jakarta in Arabic Language Study Program, there is a compulsory subject, Ashwat learning, which aims to increase hijaiyyah letters pronunciation on Sundanese students. This study aims to: (1) implement android applications to increase hijaiyyah letters on Sundanese students; (2) know the factors that support the effectiveness of android applications; (3) find out the effectiveness of using android application. The techniques of data collection are observation, interviews, and tests. The results showed that: (1) android application can help the learning process by using existing book; (2) there are several factors that affect the effectiveness of using android application; they are : (a) flexible, (b) practical, (c) interactive video and (d) additional vocabularies for Sundanese alphabets; (3) there was an influence on increasing the pronunciation of hijaiyyah letters in pretest and posttest of two classes, the results can be said effective through of the $t$-test and t-count $>t$-table $(6.82>2.145)$ while in experimental class there was an increase from an average value of $52.67 \%$ to $80 \%$.
\end{abstract}

Keywords: Android applications, implementation, hijaiyyah letters, pronunciation

\section{Introduction}

Many researchers agreed that the mother tongue of one learning Arabic affects the pronunciation of the target language that is later called interference [1]. When reading AlQur'an, all letters have to be pronounced correctly with their makhraj. The most common mistake is pronouncing a letter incorrectly with the letter position inside the mouth and the nature of the letter [2]. Understanding hijaiyyah letters is one of the important things for Muslims to be able to read the Qur'an [3]. To improve the pronunciation of hijaiyyah letters, in Islamic tertiary institutions there are courses that focus on studying this subject, namely ashwat class. Ashwat is the first part of modern linguistics and is also the study of how to pronounce and how Arabic pronunciation occurs, as well as the different characteristics of the voices pronounced [4]. Ashwat learning at the intended campus is still using conventional methods that only focus on writing letters and ignores the pronunciation of the letters so that other media are needed to complete the learning. 
Currently, the advances in technology and information have changed people's lifestyles. As time goes by, technology plays an important role not only in business or exploring the world but also as a means to get the learning material taught. One of them is using of mobile phones that are installed learning support applications so that the content needed by users can be accessed easily [5]. Learning media bring and generate happy and joy for students and renew their enthusiasm, helping to establish knowledge in the minds of students and bring learning to life [6]. The use of technology in the language learning process is expected to increase the motivation of language learners. With the help of technology, educators will easily conduct simulations on a learning material [7]. The design of technology and learning media has an influence on student learning activities and helps their abilities [8]. Using learning media and technology is not enough to create successful learning, but it requires completeness from other learning components namely learning styles and strategies [9]. The use of smartphones that are relatively easy to carry, accessible and affordable as media in learning will greatly impact students [10].

Making an android application that has made ease for Sundanese students in ashwat learning was motivated by several research results. The first researcher stated that interactive learning applications can provide convenience for children in the process of learning hijaiyyah letters [11]. The second researcher believes that used interactive learning applications can increase the interest and quality of kindergarten students [12]. The third researcher argued that there was ease in studying reading and punctuation letters using the android application, which is can be used anytime and anywhere [13]. The fourth researcher also believed that the application of hijaiyyah letters makes it easier for users, especially for beginners who want to learn about basic hijaiyyah letters [14]. The fifth researcher argued that audio-visual multimedia-based methods play an active role in eradicating Arabic illiteracy for particularly elderly people so that older people can learn and listen easily [15]. The sixth researcher argued that mobile learning applications also cause learning motivation and bring psychological influence on students, with the mobile application can be used as an interactive learning process tool because it is more fun where learning is a combination of several elements of text, images, audio, video and animation [16]. The seventh researcher believed that the android application was made to make it easier for Muslims children, teenagers or parents who have limited time to study with religious teachers and can be used at any time, given the mobile technology that has been widely used at the moment [17]. The eighth researcher believed that the learning application was made to introduce the hijaiyyah letters and the sound of the pronunciation for children aged three to nine years [18] .

The results of the study above indicate that the researchers have made a new innovation that was learning media in the form of applications in accordance with the needs of students who are similar to the researchers themselves. The researchers above makes an early childhood as objects of research, meanwhile, this research makes Sundanese students as the object of research because the student's college still face the difficulties and errors in pronunciation of hijaiyyah letters, especially hijaiyah letters that are not found in the Sundanese alphabet. So that researchers took the initiative to create an android application as a result of current technological developments that can be used by lecturers and students in ashwat learning. From the identification of problems in the background above, it can be formulated a problem that can be the focus of discussion in this study; they are: (1) how is the process of using the android application on Sundanese students?; (2) what are the factors that support the effectiveness of an android application ?; (3) how effective is the use of the android application?. 


\section{Research Method}

Qualitative researchers see meaning as socially constructed, whereas quantitative researchers consider truth as more enduring, although somewhat influenced by contexts [19]. The object of this research is Sundanese students at the State University of Jakarta. This research is using qualitative and quantitative approach, qualitative data analysis used Miles and Huberman model and quantitative data analysis used SPSS 16. The data sources of this study are: first, observation (student activities during learning), second, interviews (submitting a number of questions to lecturers and Sundanese students) and third, tests (pretest and posttest learning outcomes) data obtained through oral tests by using the android application after learning material explanation.

The research data consisted of qualitative data, which were observations during learning and interviews with lecturers and quantitative data, namely the results of learning tests obtained directly from students by comparing grades before using the android application and after using it. The final results will be obtained through the Paired Sample T-Test which is calculated using SPSS 16.

\section{Results And Discussion}

\subsection{The Application Process for Android Applications on Sundanese Students}

Some processes that must be carried out by researchers before implementing the application are as follows [20]:

Table 1. Explanation of Activities Implementation Stage

\begin{tabular}{lll}
\hline NO & Activities Implementation Stage & \multicolumn{1}{c}{ Objects } \\
\hline 1 & $\begin{array}{l}\text { Give a test in advance before starting material ashwat lesson Class } \\
\text { (Sundanese students). }\end{array}$ & Control Class \\
Describe existing material only using the textbook. & \\
Give a final test after completing one learning theme. & \\
& $\begin{array}{l}\text { Explaining the characteristics of hijaiyyah letters using the android Experimental Class } \\
\text { application. } \\
\text { Describe properly and correctly hijaiyyah video's pronunciation } \\
\text { accompanied by non-native speaker sound. } \\
\text { Give a final test after completing one learning theme. }\end{array}$ \\
\end{tabular}

In the table above showed that researchers take data before applying the android application by observation and interview. In observation, researchers come to see exactly the process of teaching and learning activities in ashwat. The result is that ashwat learning is less effective because the lecturer only uses textbook and blackboard as learning media, so students are a little bored if they only use these media. In the interview process, the researchers interviewed ashwat lecturers and asked the background of Sundanese students, which mostly came from public schools namely high schools and vocational high schools so that they did not have any basics in ashwat learning.

In the first step, researchers carried out in the control class by using pre-test and post-test. In the pretest and posttest step in control class, the researcher conducted teaching activities 
without using an android application that was used the direct method on the material letters hijaiyyah with existing textbooks. Initially, the researcher entered by explaining the characteristics of some hijaiyyah letters and then reciting the letters and asking students to follow the researchers. Then at the next meeting, the researcher explained the characteristics of the other hijaiyyah letters and recited the letters then asked students to follow the researcher. Assessment of learning outcomes was the process of giving value to learning outcomes achieved by students with certain criteria. For evaluation, the researchers asked the Sundanese students one by one to recite the hijaiyyah letters, the researcher ordered to mention the characteristics of the letters. The average value obtained by researchers in the control class was $46.67 \%$ to $49.33 \%$.

As for several factors that influence low scores achieved by students, for example, the lack of teacher attention in guiding the learning activities of the ashwat lesson and students are not accustomed to reciting hijaiyyah letters coupled with their different school backgrounds so students are still adapting to ashwat class. Overall the book used also still has shortcomings and learning is less than the maximum if only using books so that all students agree to use other media in ashwat class because they feel bored when only listening to lecturers speaking.

The second implementation in the experimental class consists of pretests and posttests as well. At pretests stage, researchers give tests without using an android applications. Before implementing Posttest, researchers teach an ashwat material using android application and give questions to know the results of the use of the application. Next, researchers share the application and explain how to use it so that students can listen directly to the pronunciation of hijaiyyah letters from the android application. Then the researcher asked the students to explain the characteristics of hijaiyyah letters and recite them properly and correctly. In this activity, the students have started to be more familiar with the existing android applications and facilitate them in knowing the characteristics and the way to pronounce properly and correctly hijaiyyah letters. Researchers have explained the use of the application before learning begins. Subsequent activities of the researcher ask one student to explain the characteristics and pronounce the letters they have heard. The average result of the grade gained by the researcher in the control class was $52.67 \%$ to $80 \%$. So it is obvious that the difference in the final value obtained from the control and experiment class then there is an influence after the use of the android application in ashwat class.

\subsection{The Cause of Effectiveness Using Android Application}

The supporting factors for the effectiveness of Android applications as follows [21] :

Table 2. Supporting factors of the effectiveness

\begin{tabular}{lll}
\hline No & Supporting factors & Explanation \\
\hline 1 & Flexible & Useful \\
2 & Practical & Offline \\
3 & Interactive Video & Video and voice of hijaiyyah letters pronunciation \\
4 & Vocabulary & Vocabulary addition of Sundanese alphabet \\
\hline
\end{tabular}

Based on table 2. Supporting factors of the effectiveness, the researchers explain the factors causing the effectiveness of using Android to increase hijaiyyah letters on Sundanese students as follows:

1. Flexible

The use of a mobile phone in a learning activity which is known as mobile learning (Mlearning) will make the learning process more flexible so that students do not have to attend a 
special place to learn [22]. So that the android application can be used whenever and wherever the Sundanese students are located to facilitate them in learning the material of hijaiyyah letters.

\section{Practical}

Easy to use because it is offline (no need for Internet network) and the android application has been installed on the smartphone of each Sundanese students then there is no more reason for them to respond to difficulties and mistakes in the process of learning the pronunciation of the hijaiyyah letters.

3. Interactive Video

In this android application not only contains video but also there is a sound of the pronunciation of hijaiyyah letters properly and correctly. So the lecturer not only teaches the theory in the book but assisted with an interactive video of the android application so that students can immediately practice the pronunciation of this hijaiyah letters.

4. Vocabulary

The vocabulary of hijaiyyah letters helps Sundanese students to know the example of each hijaiyyah letters. There are twenty vocabularies that focus on explaining the Sundanese alphabet that is not contained in the letters hijaiyyah because the majority of Sundanese students are difficult and wrong in reciting the letters. They are students of the study program of Arabic language education so that the improvement in the pronunciation of hijaiyyah letters is a must.

\subsection{The Influence of Using Android Application}

Table 3. The results of pretest and posttest

\begin{tabular}{llcc}
\hline & & $\begin{array}{c}\text { Pair 1 } \\
\text { Control class } \\
\text { Posttest-pretest }\end{array}$ & $\begin{array}{c}\text { Experiment class } \\
\text { Posttest-pretest }\end{array}$ \\
\hline Paired Differences & Mean & $\mathbf{- 2 . 6 6 7 7}$ & $\mathbf{- 2 7 . 3 3 3}$ \\
& Std.Deviation & $\mathbf{1 0 . 9 9 8}$ & $\mathbf{1 1 . 6 2 9}$ \\
& Std. Error Mean & $\mathbf{2 . 8 4 0}$ & $\mathbf{3 . 0 0 3}$ \\
& 95\% Confidence Lower & $\mathbf{- 8 . 7 5 7}$ & $\mathbf{- 3 3 . 7 7 3}$ \\
& Interval of the Upper Difference & $\mathbf{3 . 4 2 4}$ & $\mathbf{- 2 0 . 8 9 3}$ \\
T & & -.939 & $\mathbf{- 9 . 1 0 3}$ \\
Df & & $\mathbf{1 4}$ & $\mathbf{1 4}$ \\
Sig.(2- tailed) & & & $\mathbf{. 0 0 0}$ \\
\hline
\end{tabular}

From the values obtained in the control class and the respective experiments held pretests and posttests, researchers entered the value of the value into SPSS 16 applications to determine if there was any influence. The table above shows the influence of the use of android applications to the Sundanese students, it is evidenced by the increase in grades in the experimental class $52.67 \%$ to $80.00 \%$. As well as there is a value increase of $51.88 \%$ from 15 respondents, namely special Sundanese students who become objects of this research, then the application can be used in learning ashwat lesson so that the Sundanese students no longer only using the book without any direct practice [23]. But by using the application, students can learn the theory and practice directly how to form the pronunciation of each of these hijaiyah letters and can minimize the errors in the pronunciation 


\section{Conclusion}

The conclusion of this study indicate that there was an influence of using android application is to simplify and correct some mistake in pronunciation of hijaiyyah letters on Sundanese students so that appropriate to be used as a supporting media of using the existing textbooks. In the process of implementing an android application, students were more enthusiastic and not saturated when the learning process takes place and make it easier for them to understand the characteristics and pronunciation of hijaiyyah letters that are good and right so that students master the material. Seen from the results obtained after the researchers applied the application in ashwat lessons for the experimental class there was an increase from an average value of $52.67 \%$ to $80 \%$ and can be said to be effective because through t-test results namely t-count $>$ t-table $(6.82>2.145)$.

\section{References}

[1] A. O. Ayeni, "Developing Mobile Application of Interactive English Pronunciation Training to Improve EFL Students' Pronunciation Skill," J. Educ. Pract., vol. 5, no. 33, pp. 135-139, 2014.

[2] S. Hartanto, C. J. Indonesia, C. J. Indonesia, C. J. Indonesia, and C. J. Indonesia, "Model of Android Application-Assisted Arabic Letter Teaching Material Development to Improve Reading Skills and Interests for Beginners," vol. 2, no. 1, pp. 457-465, 2016.

[3] R. G. U. Mohammad Irfan, Imam Zainul Mutaqin, "Implementation of Dynamic Time Wraping algorithm on an Android based application to write and pronounce Hijaiyyah letters."

[4] A. Wahab, علم الأصوات النطقي، مطبعة جامعة مولانا مالك إبراهيم مالانق 'Ilmu-l- 'Ilmu al-Ashwat anNathiqy. 2010.

[5] S. Bulletin, "An Application of Multimedia for Basic Arabic Learning Using Fisher- Yates Shuffle Algorithm on Android Based," vol. 9771, pp. 347-355, 2019.

[6] A Arsyad, Media Pembelajaran. Jakarta: PT.Grafindo Persada, 2011.

[7] Hesti, Hardini, and Ali, "Pengembangan Bahan Ajar Berbasis Android untuk Meningkatkan Kemampuan Pengucapan pada Mahasiswa,” J. Comput. Eng. Syst. Sci., vol. 3, no. 1, p. 83, 2018.

[8] Sumaldino, Instructional Technology and Media for Learning. Jakarta: kencana, 2011.

[9] B. Pribadi, A, Media dan Teknologi dalam Pembelajaran. Jakarta: kencana, 2017.

[10] D. Kim, D. Rueckert, D. Kim, and D. Seo, "Students 'Perceptions Erceptions Rception of," vol. 17, no. 3, pp. 52-73, 2013.

[11] B. Ahaliki and Y. Djafar, "Aplikasi Pembelajaran Interaktif Huruf Hijaiyah Taman Pengajian Kota Gorontalo," J. Teknol. Inf. Indones., vol. 2, no. 1, pp. 33-37, 2019.

[12] R. Thabrani and M. S. Natsir, "Design Interactive Qur' An Learning For Kindergarten Based On Android," vol. 1, no. 1, pp. 26-31, 2018.

[13] V. M. - STMIK Nusa Mandiri Jakarta, H. M. N. - AMIK BSI Purwokerto, and W. R. - AMIK BSI Purwokerto, “Aplikasi Pembelajaran Ilmu Tajwid Berbasis Android,” Evolusi J. Sains dan Manaj., vol. 6, no. 1, pp. 91-100, 2018.

[14] M. Baca, T. Al, Q. A. Desa, and W. Kabupaten, "Perancangan Aplikasi Pembelajaran Huruf Hijaiyah Berplatform Android Untuk Madrasah Baca Tulis Al Quran Al-Fattah Desa Widodaren Kabupaten Ngawi Ika Purwanti,” 2013.

[15] R. Wulan, E. Saputra, and A. Haries, "Pengembangan Metode Cepat Membaca Huruf Hijaiyah Berbasis Multimedia dalam Rangka Pemberantasan Buta Huruf pada Lansia," J. PkM Pengabdi. Kpd. Masy., vol. 1, no. 01, p. 48, 2018.

[16] F. S. Saragih, "Aplikasi Mobile Pengenalan Huruf Hijaiyyah Berbasis Android," Universitas Sumatera Utara, 2017.

[17] I. L. Belakang, "Aplikasi Belajar dan Mengucapkan Huruf Hijaiyyah dengan Tajwid Berbasis 
Android Jurusan Teknik Informatika Politeknik Elektronika Negeri Surabaya Institut Teknologi Sepuluh Nopember Kampus ITS Keputih Sukolilo Surabaya 60111 Email: mistari87@yahoo.com Ma."

[18] W. Gunawan, "Pengembangan Aplikasi Berbasis Android Untuk Pengenalan Huruf Hijaiyah," J. Inform., vol. 6, no. 1, pp. 69-76, 2019.

[19] S. Lapan and M. Quartaroli, Qualitative Research, 1st ed. San Fransisco: Jossey Bass.

[20] Sugiyono, Metode Penelitian Pendidikan, Cetakan ke. ALFABETA, 2018.

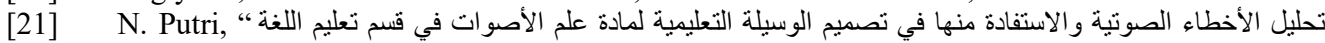
العربية بجامعة جاكرتا الحكومية, "الكية, Islamic State University of Malang, 2019.

[22] A. B. Retnomurti, N. Hendrawaty, and L. Tiwiyanti, "Development of Android-Based Protadroid Application in Pronunciation Practice Learning for Undergraduate Students," English Rev. J. English Educ., vol. 7, no. 2, p. 67, 2019.

[23] K. Saddhono, "Integrating Culture in Indonesian Language Learning for Foreign Speakers at Indonesian Universities." J. of Lang. and Lit. vol. 6 no.2 pp. 349-353, 2015 